\title{
ЯЗЫКОВЫЕ ПОКАЗАТЕЛИ КАРНАВАЛИЗАЦИИ В РОМАНАХ БОРИСА АКУНИНА И ИХ ПОЛЬСКИХ ПЕРЕВОДАХ
}

\section{Linguistic Indicators of Carnivalesque in the Novels by Boris Akunin and their Polish Translations}

Keywords: Russian literature, Polish translation, Boris Akunin, linguistic indicators, carnivalesque

Contact: Uniwersytet Śląskiw Katowicach; lukasz.geborek22@gmail.com

Теория карнавализации Михаила Бахтина, которую российский ученый представил первоначально в книге «Проблемы поэтики Достоевского», а потом дополнил в «Творчестве Франсуа Рабле и народная культура средневековья и ренессанса», интересна не только литературоведам, но также дает основу для исследований, осуществляемых лингвистами. Суть данной теории сосредоточивается прежде всего на представлении существующего и принятого обществом мира наоборот. Данное явление относится как к сфере межличностного поведения, так и к сфере общения (Rumińska 2007: 182-183). Теория карнавализации стала ключом для интерпретации отдельных художественных текстов, относящихся к различным языкам и культурам. Как подчеркивала Магдалена Руминьская, она нашла свое применение также в исследованиях польских ученых.

По словам М. Бахтина, карнавал в языке проявляется в использовании таких речевых жанров, как похвалы, проклятия, брань и т. п. (Бахтин 1990). Ученый обратил также особое внимание на телесность, прежде всего на телесный низ (в то время как верх принадлежит к духовному пласту).

В языковом плане образности такого типа можно отнести:

- Фразы, связанные с носом. Отметим, что лексема «нос» появляется во фразах или фразеологизмах, среди которых можно привести в русском языке «(не) твоим носом клевать просо» (Мокиенко, Никитина 2007) или в польском - «mieć kogoś w nosie». Однако в данном случае наиболее 
существенным является прежде всего то, что эта часть тела во времена Средневековья и позже идентифицировалась с мужским половым органом (Rumińska 2007: 193). Это, безусловно, непосредственно относится к проявлениям телесного низа. Добавим, что не случайно в книге Николая Гоголя «Нос» именно эта часть могла быть отделена от остального человеческого тела, представляя собой независимый, мыслящий, самодостаточный субъект, на первом месте которого стоит карьерный рост.

- Фразы, в которых появляется мотив бросания в кого-то специфическими веществами (Rumińska 2007: 196).

- Фразы, в которых использовался скатологический мотив. Сам М. Бахтин подчеркнул, что подтирание - это «tradycyjny familiarno-poniżający motyw skatologiczny» (Bachtin 1975).

- Фразы, которые обычно используются в языке, но в менее эвфемистической форме. Можем здесь обратиться к словам М. Бахтина, который в книге «Творчество Франсуа Рабле и народная культура средневековья и ренессанса» отмечает: «Зад - это "обратное лицо" или "лицо наизнанку"» (Бахтин 1990). Мировая литература и языки очень богаты разнообразными вариациями замещения наименований лица названиями, соотносимыми с задом, и верха низом. Один из самых простых и самых распространенных словесных и невербальных вариантов - это «поцелуй в зад» (Бахтин 1990). Ее эквивалентом в польском языке является формулировка - «саłowanie w zadek» (Rumińska 2007: 197).

- Фразы и проклятия, связанные с чертом / дьяволом (Бахтин 1990).

Феномен языкового карнавала в литературных текстах может также проявляться в сочетании смешного с драматическим, священного со светским, элитарного с массовым и т. д. (Малыса 2016: 62).

Переходя к практической части статьи, отметим, что примеры, представляющие собой языковой материал, почерпнуты из различных детективов, принадлежащих перу российского автора - Бориса Акунина, которые в целом составляют цикл под названием «Смерть на брудершафт» (польск. «Bruderszaft ze Śmiercią». Русскоязычный материал будет сопоставлен с его переводом на польский язык, автором которого является Петр Фаст.

Обращаясь к самому заглавию нашей статьи, мы хотели бы представить фрагмент, в котором находим проявление карнавализации на уровне языка. В данном фрагменте заметна трансформация общепринятой записи слов 
в русском языке или их правильного произношения. Именно такие ошибочные элементы находим в высказывании Ирмы - одной из героинь романа «Мука разбитого сердца», работающей горничной у дяди Жоржа:

Баба она была еще не старая, исключительно крепкого здоровья, но любила повторять: «Если сто, Ирма сама са себя плятит, перет лютьми стылно не nутет» (Акунин 2018: 263).

Nie była jeszcze stara i zdrowie miała jak koń, lubiła jednak powtarzać: „Jeśli co, Irma sama za sobie płacić, coby przed ludziami wstydu nie mieli” (Akunin 2015: 220).

Явление карнавализации языка в вышеприведенном примере касается записи Б. Акуниным способа произнесения слов неправильным образом. Ниже приведены правильные формы (с левой стороны) и ненормативные (с правой стороны) версии, созданные Акуниным для представления героини, фигурирующей в романе:

- что - сто;

- $\quad$ за-ca;

• платит - плятит;

• людьми - лютьми;

- будет - путет.

В этом сопоставлении замечаем, что Б. Акунин для представления ошибочного способа высказывания героини употребляет замену звонких согласных - глухими: з:с, д:т, в:П, а также смягчение сонорной согласной л:л'. В данном случае способ высказывания Ирмы напоминает произношение, характерное для людей, болеющих сигматизмом. Наряду с этим в отрывке отмечается ошибочное написание слова, однако с сохранением нормативного произношения, ср.: перед - перет. Возможно, здесь Акуниным отражается своеобразная перекличка эпох, соотносимая с так называемым олбанским языком, особенностью которого является нарушение орфографических норм при сохранении графической записи прочтения. В польском варианте переводчик избегает замены звуков, компенсируя данное явление употреблением неправильных грамматических форм, напр., «sama za sobie płacić» вместо правильного «sama za siebie będzie płacić», или ошибочного склонения по падежам польского имени существительного «ludzie»: «ludziami» вместо «ludźmi». 
Кроме того, замечаем, что в польском переводе П. Фаст употребил разговорный союз «соbу», который обозначает «żeby» или «аbу», в предложении, неправильном с точки зрения использования в нем грамматических форм слов или их лексической сочетаемости: «сoby przed ludziami wstydu nie mieli» (Akunin 2015: 220), вместо: «żeby przed ludźmi wstydu nie było».

Способ высказывания Ирмы в польском переводе может указывать на то, что скорее всего она была малообразованна, а также имела деревенское происхождение. Однако благодаря всем представленным переводческим решениям данный фрагмент также удачно вписывается в теорию карнавализации, полностью отражая замысел автора текста оригинала.

В случае этого примера следует также обратить внимание на употребление переводчиком польского фразеологизма, описывающего человеческую черту, в котором появляется мотив животного: «mieć zdrowie jak koń», для передачи фразы «(быть) крепкого здоровья». Может быть, данное решение было оправдано фактом, что Б. Акунин в своих романах очень часто сравнивает черты героя с чертами разных животных: не только относительно внешнего вида, но также его способа поведения. Этот аспект проиллюстрируем на нескольких, по-нашему мнению, наиболее ярких примерах: «агенты (...) повылезали из нор, будто кроты перед грозой» (Акунин 2018: 13). - «agenci (...), powyłazili ze swoich nor jak krety przed burzą» (Akunin 2015: 12); или «та, дурочка, смотрела на мать влажными коровьими глазами» (Акунин 2018: 31). - «a ta głuptaska patrzyła na matkę wilgotnymi, krowimi oczami» (Akunin 2015: 28).

Употребление в данном отрывке фразеологизма, который не только отражает значение русскоязычной фразы, но дополнительно указывает на стиль, использованный автором текста оригинала, можно, без сомнений, признать хорошим переводческим решением.

В дальнейшей части романа «Мука разбитого сердца» находим очередное предложение, высказанное Ирмой:

Вернувшегося воина встретила одна горничная. Оросила слезами и всё повторяла «какой плёхой стал, коза да кости». Сбегла куда-то, принесла платок, на котором все эти дни вышивала ангелов. Они-то, по ее словам, и уберегли «Алёсеньку» от гибели (Акунин 2018: 263).

Frontowego bohatera przywitała jedynie gosposia. Zaprosiła go tzami i ciagle powtarzała: , Jaki to chudzieńki się zhobil, skóha i kości”. Pobiegła gdzieś, przyniosła chustkę, na której przez wszystkie te dni wyszywała jakieś anioły. To one, wedtug jej opinii, , uhatowaty Alosieńkę” od zguby (Akunin 2015: 221). 
В этом примере снова находим стилизацию языка Ирмы. В выражении «какой плёхой стал» прежде всего обращает на себя внимание факт, что Ирма неправильным образом акцентирует прилагательное «плохой», в котором ударение падает на последний слог. Об этом свидетельствует написание слова как «плёхой». Известно, что слог, в котором появляется буква «ё», в русском языке (согласно фонетическим правилам) всегда находится под ударением. Кроме того, буква «ё» указывает на смягчение произношения предшествующего согласного. Таким образом, можем принять, что Ирма совершает ошибки и в этой области культуры языка.

Следует также обратиться к дальнейшей части данного предложения, в котором вновь сталкиваемся с заменой одной буквы во фразеологизме «кожа да кости». Речь идет о том, что Б. Акунин заменяет букву «ж» на «з», благодаря чему появляется название животного - «коза». Имея в виду тот факт, что Ирма совершает ошибки также в ударении слов, можем предполагать, что она не обратила внимание на то, что в случае лексемы «кожа» ударение падает на первый слог, а не как в случае слова «коза» - на второй (последний). Все это приводит к созданию дополнительного комического эффекта.

В переводе данной особенности на польский язык замечаем, что П. Фаст решает представить Ирму как человека, у которого есть проблемы с произношением согласного «гі, которые, видимо, связаны с особенностями речи ее родного языка. Таким образом, используются такие польские слова, в которых оправдана замена «r» другим согласным звуком, т. е. «h»: «zhobił» (вместо правильного - «zrobił») или же «skóha» («skóra»).

Этим словам предшествует принадлежащее разговорному стилю прилагательное «chudzieńki», которое является уменьшительно-ласкательной формой имени прилагательного «сhudy». Согласно словарю польского языка Витольда Дорошевского, лексема «chudzieńki» характерна прежде всего для восточных регионов Польши.

В указанном фрагменте в авторское повествование вводятся слова, которые прозвучали из уст Ирмы. В тексте исходного языка - это неправильная запись уменьшительно-ласкательной формы имени «Алеша» в родительном падеже, т. е. «Алёсеньку» вместо «Алёшеньку».

Однако в тексте целевого языка переводчик решил расширить появившиеся в тексте слова Ирмы. Так, в цитировании добавляется глагол «uratować» в соответствующей уже отмеченным особенностям записи - «uhatowały Alosieńku». Это непосредственно отсылает польского читателя к отмеченной уже 
ранее специфике произношения данной героини. Можно предположить, что представление в кавычках только самой формы имени могло бы стать недостаточным для осознания и расшифровки польским читателем ошибочного употребления наименования лица.

Таким образом, все принятые переводчиком решения в области передачи языка одной из героинь, являются удачными. Они, как правило, вызывают тот же коммуникативный эффект, который был создан Борисом Акуниным. Лишь в случае языковой игры, основанной на замещении слова «кожа» словом «коза» во фразеологизме «кожа да кости», можно говорить об утрате дополнительного комического звучания в переводе.

Опишем уже более кратко некоторые другие проявления карнавализации, которые были обнаружены нами в рассматриваемом цикле произведений Акунина. В теоретической части нашей статьи мы обратили внимание на то, что карнавализация в языке может проявляться во фразах, связанных с чертом / дьяволом. Также такой фрагмент находим в детективе, уже само заглавие которого - «Младенец и черт» - содержит соотнесение к интересующей нас cфepe:

Черт с ним, не в нем дело (Акунин 2018: 49).

Wszystko jedno, nie o niego chodzi (Akunin 2015: 42).

Как можно заметить на основании двух отрывков, русское и польское выражения сильно отличаются, несмотря на тот факт, что польский язык дает возможность передать фразу «черт с ним» буквально, т. е. «do diabła z nim», таким образом вызывая тот же коммуникативный эффект. Переводчик, употребляя нейтральную фразу «wszystko jedno» (что в русском языке обозначает «все равно») не только утрачивает элемент карнавализации языка, но прежде всего сглаживает данную фразу, из-за чего утрачивается экспрессия, заключенная в исходном тексте.

Последний, выбранный нами для анализа пример касается скрытого в описательной форме ругательства, что также непосредственно относится к показателям карнавализации языка:

Выругавиись по матери, капитан разворошил весь сверток (Акунин 2018 : 49).

Kapitan zakląl, mówiąc coś o jakiejś matce, i zacząt wyciagać pranie z zawiniątka (Akunin 2015: 44). 
Представленная фраза «выругавшись по матери» непосредственно отсылает к выражению «ёб твою мать», в котором именно эта лексема появляется. Функциональным эквивалентом данного ругательства в польском языке является «kurwa mać» или «kurwa jego mać». Однако разница между двумя версиями заключается в том, что в русском языке, лексема «мать» принадлежит современному литературному языку, в то время как согласно словарю польского языка, слово «тас́» - это уже устаревшая форма современного слова «matka». Вместе с тем декодирование фразы вторичным читателем не должно вызывать трудностей.

Подводя итоги, мы хотели бы еще раз обратить внимание на факт, что теория карнавализации М. Бахтина в языковом плане может проявляться разными способами. Наряду с ругательствами отмечаются и более мягкие способы ее выражения. К ним относятся как фразы с мотивом дьявола, так и носа и др. Представленные нами примеры из книг современного русского писателя Б. Акунина, показали, что сам автор часто использует в своих детективах именно такие обороты. Хотя данная статья является лишь введением в проблему перевода показателей проявлений карнавализации языка, то нам удалось заметить, что в польских переводах они их передача была осуществлена с учетом большинства особенностей в этом плане исходных текстов. Несмотря на то, что во время анализа мы нашли пример, в котором переводчик употребил слишком нейтральный эквивалент («черт с ним» - «wszystko jedno»), то следует подчеркнуть, что П. Фаст, используя разные решения, отдает польскому читателю все то, что без сомнения хотел бы ему передать и сам Акунин.

\section{Summary}

The following paper constitutes an attempt to describe carnivalesque theory by Mikhail Bakhtin in the aspect of its appearance in the literary text on the language level. Language material was taken from the books of Russian author Boris Akunin. The analysis which was performed by the author of the article concerned the comparison of the perception of language carnivalesque manifestations into output reader when compared with their perception by the reader of the translation into Polish. During the analysis there was noticed that the language carnivalesque in Russian author novels constitutes popular phenomena and the translator in most of the cases succeeded in keeping the original sens through the use of different translation techniques. 


\section{Литература}

Акунин, Б. Смерть на брудершафт. Младенец и черт (фильма первая), Мука разбитого сердияа (фильма вторая). Москва: Издательство АСТ, 2018.

Бахтин, М. Творчество Франсуа Рабле и народная культура Средневековья и Ренессанса. Москва: Художественная литература, 1990. Режим доступа: http://www.infoliolib.info/philol/bahtin/bahtmain.html (28.02.2020).

Малыса, О. Карнавальный мир детективов Бориса Акунина в польских переводах. In: Lubocha-Kruglik J., Małysa, O. (eds.) Przestrzenie przekładu. Katowice: Wydawnictwo Uniwersytetu Śląskiego, 2016, s. 61-72.

Мокиенко, В. М., Никитина, Т. Г. Большой словарь русских поговорок. Москва: Олма Медиа Групп, 2007. Режим доступа: https://dic.academic.ru/dic.nsf/ proverbs/33783/\%5B\%D0\%9D\%D0\%B5\%5D (22.04.2020).

Akunin, B. Cykl „Bruderszaft ze śmiercia”: Młokos i diabel, Cierpienie złamanego serca. Zakrzewo: Replika, 2015.

Bachtin, M. Twórczość Franciszka Rabelais'go a kultura ludowa średniowiecza i renesansu, przeł. A. i A. Goreniowie. Kraków: Wydawnictwo Literackie, 1975.

Rumińska, M. Michała Bachtina teoria karnawalizacji języka. In: Mazur, J., Rumińska, M. (eds.) Humor i karnawalizacja we współczesnej komunikacji językowej. Lublin: Wydawnictwo Uniwersytetu Marii Curie-Skłodowskiej, 2007, s. 181202.

Режим доступа: http://www.edupedia.pl/map/dictionary/id/6_slownik_frazeologiczny. html (2020-02-28).

Режим доступа: https://www.portel.pl/kina-i-teatr/the-metropolitan-opera-nos/68565 (2020-02-28).

Режим доступа: https://sjp.pwn.pl/sjp/mac;2480407.html (2020-04-22).

Режим доступа: https://sjp.pwn.pl/slowniki/coby.html (2020-04-22).

Режим доступа: https://dic.academic.ru/dic.nsf/dic_synonims/248163/ёб (2020-0422).

Режим доступа: https://sjp.pwn.pl/doroszewski/chudzienki;5417238.html (2020-0422). 